\title{
EFFECTS OF RIVER REGULATION ON PLANT DISPERSAL AND VEGETATION
}

\author{
Oksana OMELCHUK * and Bohdan PROTS **
}

\begin{abstract}
* National Academy of Sciences of Ukraine, State Museum of Natural History, Teatralna Street 18, Lviv, Ukraine, UA-79008, omelchukoksana@gmail.com

** WWF Danube-Carpathian Programe in Ukraine, Mushaka Street 42, Lviv, Ukraine, UA-79011, bohdan.prots@gmail.com
\end{abstract}

DOI: 10.1515/trser-2015-0009

KEYWORDS: river corridors, seed bank, river regulation, plant dispersal invasions.

\section{ABSTRACT}

This study compares the vegetation and seed deposits of free-flowing parts of a river with those regulated by straightening, as well as identifying the correlation between the breadth of the river-bed, existent vegetation and distribution of plant species along the river corridor. The 31 sampling plots in the Ukrainian Carpathians, at an equal distance of four $\mathrm{km}$ from each other, were positioned across different vegetation zones. Vegetation and seed bank data were collected. The study showed that effective distribution of plants has a place in native (non-regulated) river-corridors with a river-bed breadth of $15-30 \mathrm{~m}$. The reduction and straightening of the river-bed decrease the number of species that can be dispersed along river. The percentage of seeds of alien species greatly increases, from $0.1 \%$ in the free-flowing to $10 \%$ in the regulated parts of rivers. River regulation causes transformation of native vegetation communities in these plots into associations of invasive herbaceous perennial species; such as associations of Helianthus tuberosus and Solidago gigantea. The analyses do not show a clear link between the breadth of the river-bed and number of invasive species in the vegetation community. The research suggests that river regulation has a clear negative effect on vegetation by decreasing the resistance of plant communities to alien species.

RESUMEN: Efecto de la regulación fluvial en la vegetación y dispersión de plantas.

En este estudio se hace una comparación entre vegetación y depósitos de semillas en cuerpos de deriva, y la regulación fluvial hecha mediante obliteración de flujo; así mismo se identifica una correlación entre la anchura del cauce, la vegetación existente y la distribución de las especies de plantas observadas a lo largo del corredor fluvial. En el área de los Cárpatos ucranianos, en distintas zonas con vegetación, se establecieron 31 sitios de muestreo dispuestos de forma equidistante cada cuatro $\mathrm{km}$ unos de otros. Se realizó una colecta de la vegetación y se tomaron datos del banco de semillas. El estudio mostró que la distribución efectiva de las plantas tiene lugar en corredores fluviales autóctonos (no regulados) con un cauce de entre 15 y 30 metros. La obliteración del cauce reduce el número de especies que pueden dispersarse a lo largo del río. El porcentaje de semillas de especies foráneas se incrementa dramáticamente de $0,1 \%$ en los objetos flotantes, hasta $10 \%$ en los segmentos regulados de los ríos. En estos lugares, la regulación fluvial transforma las comunidades vegetales nativas a asociaciones de especies de hierbas invasivas como Helianthus tuberosus y Solidago gigantea. Los análisis no muestran una relación clara entre el cauce del río y el número de especies invasivas en las comunidades de plantas. Esta investigación sugiere que la regulación fluvial tiene evidentes impactos negativos en la vegetación, provocando una disminución en la resistencia de las comunidades vegetales nativas a las especies de plantas invasivas. 
REZUMAT: Efecte ale regularizării râurilor asupra speciilor de plante şi a vegetaţiei.

Prezentul studiu compară vegetaţia şi depozitele de seminţe din sectoarele liber curgătoare ale râurilor cu cele regularizate prin rectificarea cursului, precum şi identifică corelaţia dintre lăţimea albiei, vegetaţia existentă și distribuția de specii de plante de-a lungul coridorului râului. Cele 31 de staţii studiate, situate la o distanţă de patru kilometri una de celalaltă, au fost alese în zone cu diferite tipuri de vegetaţie. Au fost colectate atât date de vegetaţie, cât şi a băncilor de seminţe. Studiul arată că distribuţia actuală a speciilor de plante este legată de coridoarele naturale, neregularizate cu o lăţime a albiei de 15-30 m. În partea redusă şi rectificată a albiei scade numărul speciilor distribuite de-a lungul râului. Procentajul de seminţe ale speciilor neofite creşte extrem de mult de la $0,1 \%$ în sectoarele liber curgătoare la $10 \%$ în părţile regularizate ale râurilor. Regularizarea de râuri cauzează transformarea comunităţilor naturale de vegetaţie în aceste sectoare spre comunităţi de specii de plante perene, invazive cum sunt cele de Helianthus tuberosus şi Solidago gigantea. Analiza nu arată o relaţie clară între lăţimea albiei şi numărul de specii invazive în asociaţia de plante. Cercetarea desfăşurată arată că regularizarea râurilor are efecte negative clare asupra vegetaţiei ripariene prin scăderea rezistenței comunităţilor de plante la specii neofite.

\section{INTRODUCTION}

As functional linkages between sites, floodplain ecosystems of the Transcarpathia are an important component of ecological corridors. They are essential to maintaining and restoring a degree of coherence in fragmented ecosystems. These corridors are naturally existing connections, where the focus is on conservation of biodiversity (Bennett and Mulongoy, 2006). River corridors encompass sharp gradients of environmental factors and ecological processes. Thanks to these characteristics they has important functional role (Curtean-Bănăduc et al., 2014) and are considered hotspots of species diversity (Gepp et al., 1985; Schneider and Schariz, 1986; Naiman et al., 1993; De’camps and Tabacchi, 1994; Naiman and De'camps, 1997).

The rivers corridors are unique in regard to biodiversity: Transcarpathia harbours refuges of ancient primeval riverine forests of Europe. The territory covered by fragmented primeval Pannonian riverine forests consists of 1,400 hectares, $70 \%$ of which are unique oakashen forests. This is the same size as the one covered by primeval riverine forests in Austria, Hungary and Slovenia, combined. Unfortunately, 13,000 ha of floodplain forests within the Transcarpathian Plain have been destroyed over the last century. A similar situation has been identified in neighboring Slovakia as well. The decrease of riverine forest areas in the northeastern part of the Hungarian Plain during the last century is calculated to be $41 \%$ (transboundary lowland Slovakia) and 44\% (Transcarpathia), respectively (Prots, 2010).

Currently, river corridors in the Transcarpathia are threatened by strong human impact as well as building of small hydroelectric power stations, dams and river bed straightening. These activities change the native hydrologic regime and may cause the destroying of river corridor functions. The studies showed the negative effects of fragmentation by dams on river corridors (Petts, 1984; Dynesius and Nilsson, 1994). Vegetation changes following hydrological alterations have been documented for vascular plants (Nilsson et al., 1991, 1993; Nilsson and Jansson, 1995; Toner and Keddy, 1997) and for bryophytes (Englund et al., 1997) as well, but there are few observations on how river regulation by dams and river bed straightening affects the plant dispersal. We assume that baseless river regulation may increase an invasion of alien plants, as well as negatively affect species' diversity and plants' dispersal. More knowledge about this is needed for sustainable development of floodplain ecosystems. 
At first, the river regulation by dams and river bed straightening, caused the contraction of river bed and floodplains. Therefore this paper will focus on the correlation between the breadth of river-bed and the extant to which vegetation and plants species distribute along river corridors.

\section{MATERIALS AND METHODS}

\section{Study area}

This study was carried out in the riparian ecosystems of Ukrainian Transcarpathia (Zakarpatska Oblast Province; neighbouring Hungary, Slovakia, Romania and Poland). This territory has a total area of $12,800 \mathrm{~km}^{2}$ and is located in the Carpathian Mountains region of Western Ukraine. The region's climate is moderate and continental with about 700-1,500 mm of rainfall per year. The average temperature in summer is $+21^{\circ} \mathrm{C}$ and $-4 \mathrm{C}$ in winter (Bodnar, 1987).

The main river of the Transcarpathian region is Tisa (Tisza), which is a part of the Danube basin. The river basin of Tisa includes more than 9,000 rivers and streams, the most important being Borzhava, Latorytsia and Uzh (Pop, 2003; Anychin and Spyrydorov, 1947). The Uzh and Latorytsia were chosen for our study as the two biggest rivers with similar environmental conditions. The Uzh is $133 \mathrm{~km}$ long (112 km of which are on the Ukrainian territory), the basin area is 2,750 km²; Latorytsia is $188 \mathrm{~km}$ long (156.6 km on Ukrainian territory), with a basin area of $7,680 \mathrm{~km}^{2}$. Both rivers have their headwaters in the high Carpathian Mountains at altitudes of one thousand (Uzh) eight hundreds metres (Latorytsia) crossing a region of low volcanic mountains and lowland plain. The average water consumption in the mountain region is $8.8 \mathrm{~m}^{3} / \mathrm{s}$. At the source, rivers are very rapid, but in the lowland plain, the river bed widens and the rate of water decreases; the average flow velocity being $0.4-0.6 \mathrm{~m} / \mathrm{s}$.

The strong and spontaneous floods, up to eight to nine per year (normally caused in March-August by intense rains), promote considerable differences in water levels with steep rises and following falling levels, are a special feature in the regime of both rivers. During the growing season, the water level is highest in March-July and usually lowest in AugustSeptember (Herenchuk, 1981).

\section{Sampling and data collection}

In total, 31 sampling plots (16 along Uzh and 15 along Latorytsia), at an equal distance of four km from each other, were positioned across three different zones. These included high mountains, volcanic mountains and lowland plain (Fig. 1). The 28 sampling plots were located at free-floating parts of rivers (16 along Uzh and 12 along Latorytsia); three sampling plots were located along Latorytsia at the regulated part. The sampling plots were located on the river shore exposed to flooding.

A permanent vegetation quadrate of $200 \mathrm{~m}^{2}$ was established at each sampling plot. Vegetation composition was determined during August 2010, using the Braun-Blanquet methodology (Braun-Blanquet, 1964).

The composition of the seed bank was determined (Ter Heerdt et al., 1996) by sampling and carefully digging up the sediment (Ter Heerdt et al., 1996) using a standard 6.9 $\mathrm{cm}$ diameter and $6.3 \mathrm{~cm}$ height metal cylinder (volume is $235,46 \mathrm{~cm}^{3}$ ). The seed bank was sampled in five replicates at each of the thirty one plots. The five samples from the same plot were mixed and one averaged sample of soil was prepared. 


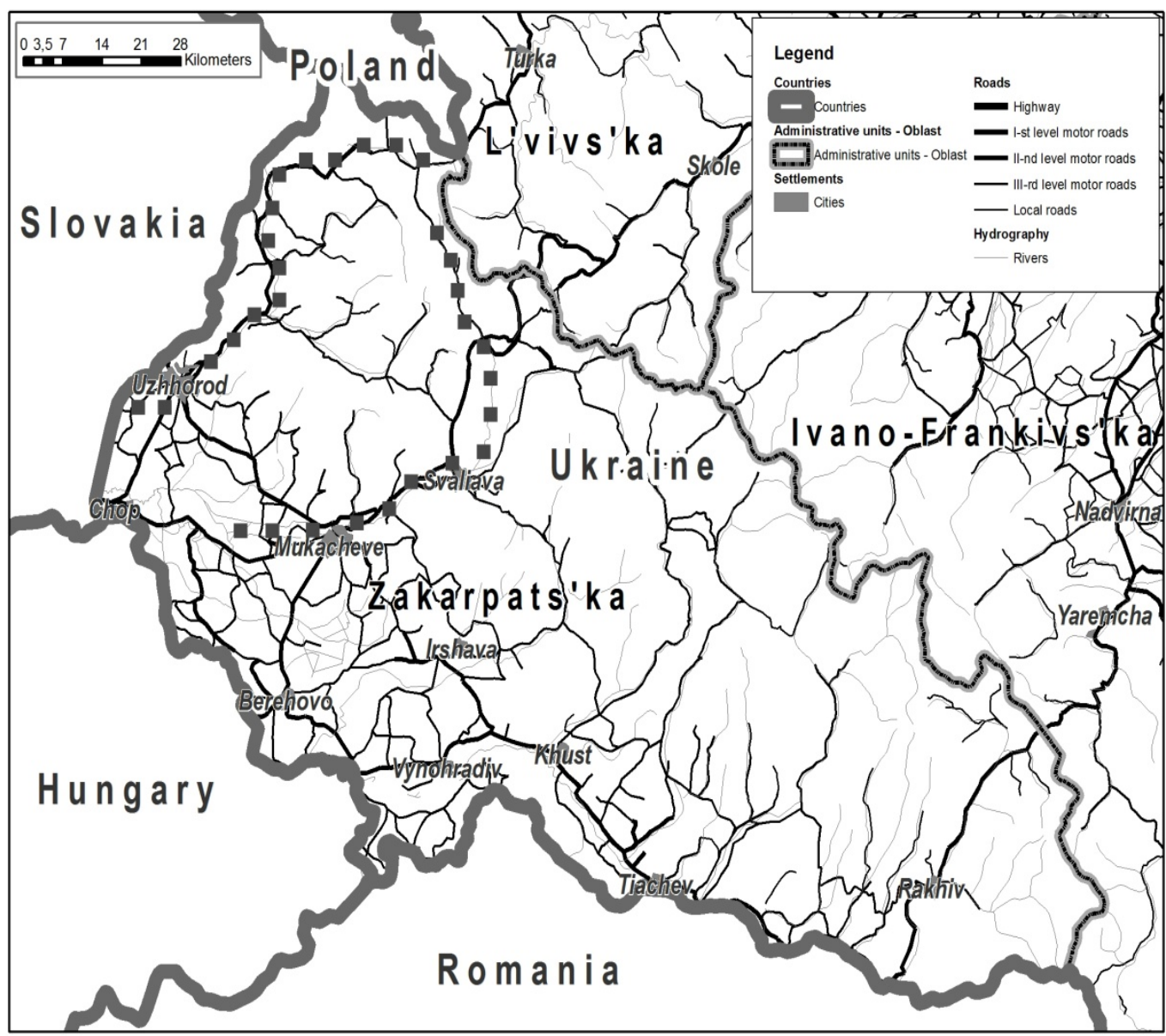

Figure 1: The location of samples plots (black cubes) in the Transcarpathia of Ukraine.

In laboratory pebbles and large organic remains were singled out. At the next step all samples were sieved twice; first through a five millimeters mesh, then large seeds were selected from dropout manually, sifting under binocular viewing. Soil that had passed through the first sieve was sieved through the one millimeter mesh, which was only slightly larger than the mean particle size of the sand, for separating small seeds.

All separated seeds from the same plot were collected, calculated and then identified using a printed atlas for seeds identification (Maysuryan and Atabekova, 1978) and electronic identification of seeds (http://seeds.eldoc.ub.rug.nl/root/).

\section{RESULTS AND DISCUSSION}

The extant vegetation cover at each plot has been studied along Uzh and Latorytsia rivers. This study shows the contrasts in the species richness floodplain ecosystems of regulated and free-floating rivers. The river-bed straightening shows a rise in the number of invasive species by decreasing resistance of vegetation communities to alien plants invasion. It causes forming of synanthropic vegetation types at the regulated parts of rivers. 
The analyses showed that on 28 plots the innate floodplain vegetation cover is intact, though at some plots it was restored after the building of dams and bridges. At the upper course of both rivers the plants communities are presented by class Rhamno-Prunetea spinosae Rivas Goday and Borja Carbonell 1961 ex R. Tx. 1962. Further downstream, where vegetation cover is being restored after disturbances, it forms wet meadows, which belong to associations of classes Molinio-Arrhenatheretea R. Tx. 1937. At the Pannonian lowland, where the riverbed was widened from 20 to 40 meters, the native vegetation is presented by floodplain forest associations of classes Salicetea purpureae Moor 1958 and Querco-Fagetea Br.-Bl. et Vlieger 1937 (Tabs. 1 and 2).

It has been defined, that river bed straightening has caused the most crucial impact on extant floodplain vegetation by contraction of river-bed and floodplains. The innate floodplain vegetation on the three plots located along the fragment of Latorytsia River, that has been regulated, is replaced by invasive species. River-bed at this territory has been reduced from 40 45 to 10 meters and existent floodplain forests and bushes have been cut out. The vegetation at these plots is represented by perennial invasive herb communities that belong to associations of Helianthus tuberosus Hilb. 1972 and Solidago gigantea Hilb. 1972 of the class Artemisietea vulgaris Lohmeyer et al. ex von Rochow 1951 (Tab. 2).

The percentage of alien species abundance from all the vegetation cover at the study plots located along unregulated, as well as regulated parts of the rivers, doesn't show a strict correlation with the breadth of river-bed and varies from $15.6 \%$ to $27.3 \%$. But the abundance of species doesn't show the participation of a part of these species in the studied communities.

Table 1: The description of sample plots along Uzh River.

\begin{tabular}{|c|c|c|}
\hline $\begin{array}{l}\text { Vegetation } \\
\text { type }\end{array}$ & $\begin{array}{l}\text { Breadth } \\
\text { of } \\
\text { riverbed }\end{array}$ & $\begin{array}{c}\text { Location of the plots } \\
\text { (enumeration of the plots } \\
\text { starts from river headwaters) }\end{array}$ \\
\hline $\begin{array}{l}\text { Class Rhamno-Prunetea spinosae } \\
\text { Rivas Goday and Borja Carbonell } \\
1961 \text { ex R. Tx. } 1962 \\
\text { Pruno-Ligustretum R. Tx. } 1952\end{array}$ & $10-20$ & $\begin{array}{l}\text { Plots no. } 1-2 \text { at Uzh River, } \\
\text { close to the village of Luh }\end{array}$ \\
\hline $\begin{array}{l}\text { Class Molinio-Arrhenatheretea } \\
\text { R. Tx. } 1937 \\
\text { Ranunculo repentis-Alopecuretum } \\
\text { geniculati R Tx. } 1937\end{array}$ & 15 & $\begin{array}{l}\text { Plot no. } 3 \text { at Uzh River, close } \\
\text { to the village of Stavne }\end{array}$ \\
\hline $\begin{array}{l}\text { Class Salicetea purpureae Moor } 1958 \\
\text { Salicetum purpureae Wendelberger- } \\
\text { Zelinka } 1952 \\
\text { Salicetum albae Issler } 1926 \\
\text { Salicetum fragilis Passarge } 1957\end{array}$ & $15-40$ & $\begin{array}{l}\text { Plot no. } 4-16 \text { at Uzh River, } \\
\text { close to village of Stavne, } \\
\text { Zhornava, Kostryna, Sil, } \\
\text { Velykyi Bereznyi, } \\
\text { Zarichovo, Perechyn, } \\
\text { Nevytske, town of Uzhgorod }\end{array}$ \\
\hline
\end{tabular}


Table 2: The description of sample plots along Latorytsia River.

\begin{tabular}{|c|c|c|}
\hline $\begin{array}{l}\text { Vegetation } \\
\text { type }\end{array}$ & $\begin{array}{l}\text { Breadth } \\
\text { of } \\
\text { riverbed }\end{array}$ & $\begin{array}{l}\text { Location of the plots } \\
\text { (numeration of the plots } \\
\text { starts from river headwaters) }\end{array}$ \\
\hline 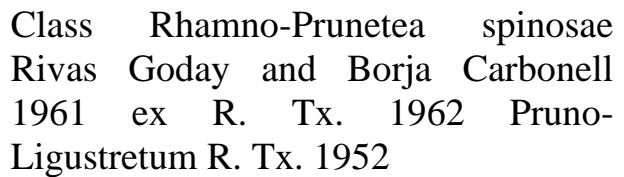 & 15 & $\begin{array}{l}\text { Plot no. } 1 \text { at Latorytsia } \\
\text { River, close to village of } \\
\text { Bilasovytsia, downstream }\end{array}$ \\
\hline $\begin{array}{l}\text { Class Salicetea purpureae Moor } 1958 \\
\text { Salicetum fragilis Passarge } 1957 \\
\text { Salicetum purpureae Wendelberger- } \\
\text { Zelinka } 1952 \\
\text { Salicetum eleagno-purpureae }\end{array}$ & $15-30$ & $\begin{array}{l}\text { Plots no. 2-11 at Latorytsia } \\
\text { River, close to villages of } \\
\text { Tyshiv, Nyzni Vorota, } \\
\text { Pidpolozzia, Gankovytsia }\end{array}$ \\
\hline $\begin{array}{l}\text { Class Querco-Fagetea Br.-Bl. et } \\
\text { Vlieger } 1937 \text { Fraxino-Populetum Jurko } \\
1958\end{array}$ & 40 & $\begin{array}{l}\text { Plots no. } 12 \text { at Latorytsia } \\
\text { River, close to village of } \\
\text { Suskovo }\end{array}$ \\
\hline 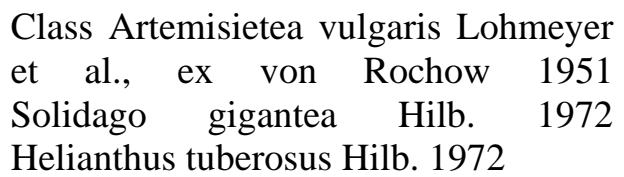 & 20 & $\begin{array}{l}\text { Plots no. } 13-15 \text { at Latorytsia } \\
\text { River, close to village of } \\
\text { Velyki Lychky }\end{array}$ \\
\hline
\end{tabular}

Also, the analysis doesn't show a clear link between the breadth of river-bed and the number of invasive species in the vegetation communities. Perhaps the correlation between species richness and the river-bed straightening may not be explained by the direct impact of straightening. It could be explained by the indirect effect of vegetation cover fragmentation. This illustration is corroborated by the results of another study (Andersson et al., 2000). The group of researchers compared two adjacent rivers, one freeflowing and the other regulated, from northern Sweden. They estimated the floristic continuity along the two rivers by comparing the drift flora with the riparian flora further upstream. It was shown, that the floristic continuity was higher in the free-flowing river compared to the regulated river.

The comparison of non regulated and regulated neighbouring plots (with the same riverbed, $20 \mathrm{~m}$ ) has been arranged along Latorytsia River. The graph shows that the percentage of share of alien spontaneous species for non regulated plots varies from $8 \%$ to $18 \%$. In the same time, percentage of alien species increased to $82 \%$ at the plots located along the part of river that was regulated by straightening. The graph shows the negative impact of regulation by straightening on natural floodplain vegetation $(\mathrm{P}=0.012)($ Fig. 2$)$.

The study of the seed bank illustrated the correlation between the breadth of the riverbed and the number of seeds deposited in the silt. The average number of seeds per plot for the upper course of the rivers is 51 seeds per plot for Uzh and 40 for Latorytsia. The biggest seed richness was shown in the plots which are located with the breadth of river-bed between 15 and 30 meters. The numbers of seeds in the silt are lower in the lowland area $(\mathrm{P}=$ 0.04) (Fig. 3). 


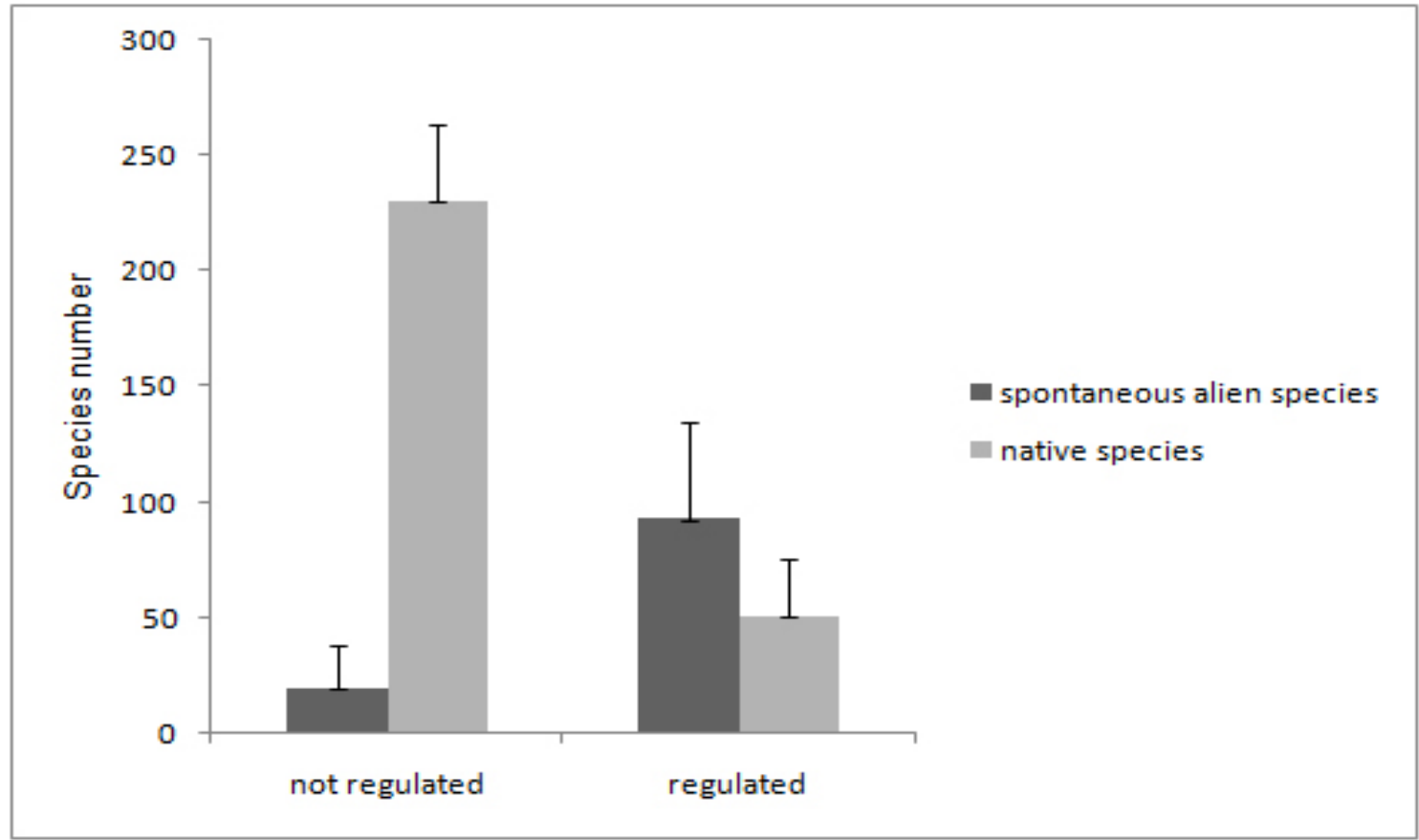

Figure 2: The number of native and invasive species that occur in floodplain vegetation along regulated and non regulated parts of Latorytsia River and standard deviation of meanings.

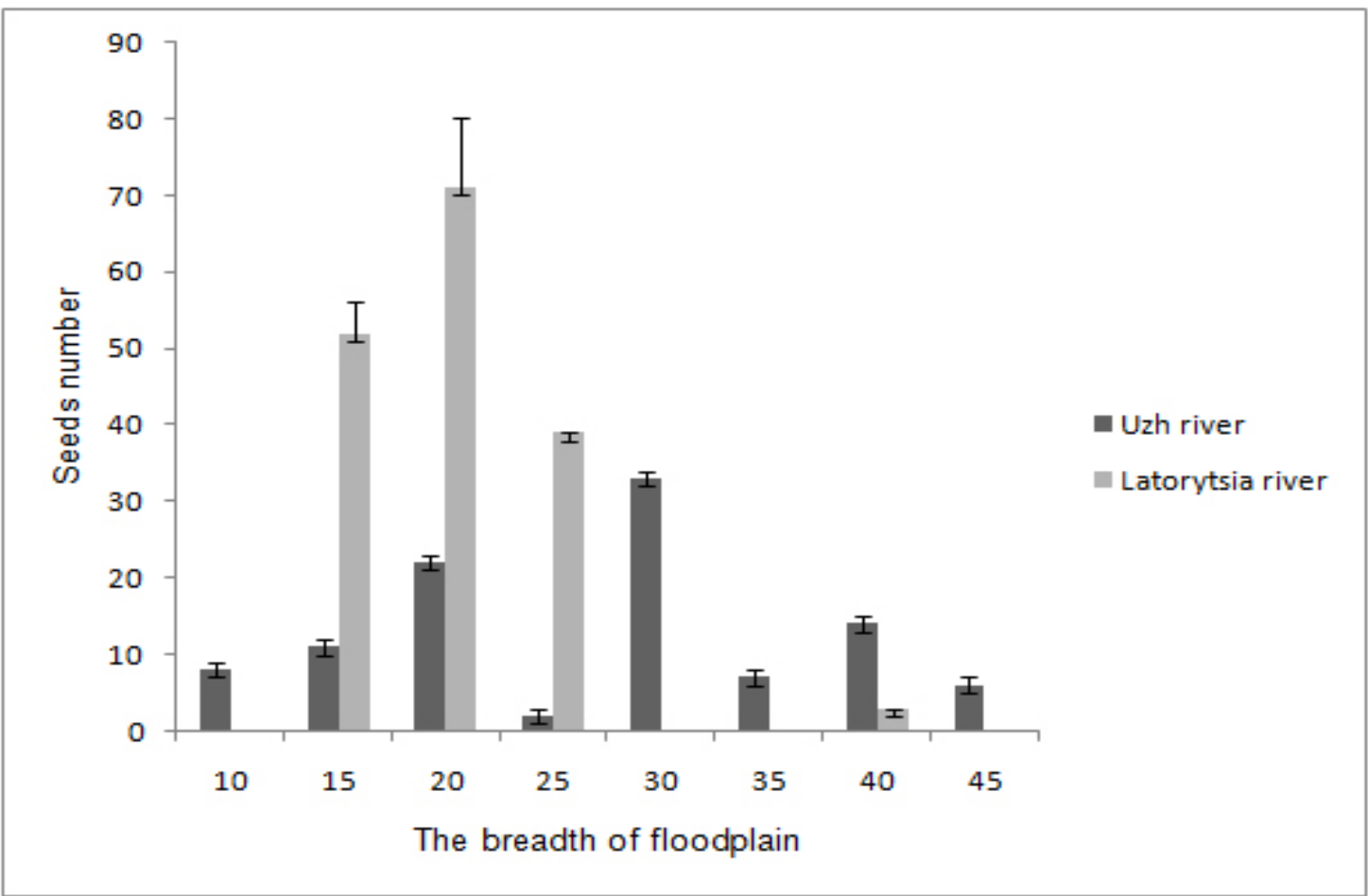

Figure 3: The breadth of river-bed and species diversity of seeds accumulated in the silt for Uzh and Latorytsia rivers and standard deviation of meanings. 
Furthermore, the result of this specific study showed the clear significant impact of riverbed regulation also on seeds dispersal. The floristic comparison of seeds deposits from regulated and non regulated river parts suggests that the percentage of alien species increases after regulation. The considerable participation of alien species in seed bank may support the further fast invasion of alien species into natural vegetation communities.

\section{CONCLUSIONS}

The comparison of seed bank for the neighbouring plots showed that percentage of alien species seeds increases sharply from $0.1 \%$ at the free-floating natural parts of river to $10 \%$ at the regulated parts.

The plots located at submontane zone are characterized by bigger species richness and bigger number of seeds in the silt. This situation may be explained by the fact that in these parts of the rivers, the river flow is good enough for transporting numerous species and seeds can be accumulated on shores of gently sloping rivers. The river straitening increases the rivers drift, which could have a negative impact on diversity and survival of seeds.

The species similarity of extant vegetation and closed seed bank is very low. Moreover, the comparison of seed deposits with potential of source communities further upstream in the rivers suggests that an upstream-downstream similarity decreases after regulation. This result is in conformity with literature data (Andersson et al., 2000; Skoglund, 1990). The probable mechanism for this is the restriction of transported diasporas by river regulation. Nilsson and Jansson (1995) concluded the fact that regulated rivers cannot create their own pattern of species richness by means of long-distance dispersal of plants, i.e. there is no regional dispersal of the flora, but a dependence upon local contributions only.

This specific study showed the fact that effective distribution of plants has a place in native (not regulated) river-corridors with the breadth of river-bed within 15-30 meters. The reducing and straightening of the river-bed can decrease the number of species that could be dispersed along river. It makes the restoring of wet meadows at the places where floodplain forests and bushes were cut out impossible. Instead, river regulation cases transform the native vegetation communities at these plots in associations of invasive perennial herbs species, such as associations with dominance of Helianthus tuberosus and Solidago gigantea or S. canadensis. However, to provide a better understanding of the effects of river regulations on riparian vegetation and seed dispersal (Willson, 1992; Wilson et al., 1990), future studies are needed. 


\section{REFERENCES}

1. Andersson E., Nilsson C. and Johansson M. E., 2000 - Effects of river fragmentation on plant dispersal and riparian flora, Regulated Rivers: Research and Management 16, 1, 83-89.

2. Bennett G. and Mulongoy K. J., 2006 - Review of experience with ecological networks, corridors and buffer zones, Secretariat of the Convention on Biological Diversity, Montreal, Technical Series, 23, 100.

3. Bodnar V. L., 1987 - Natural resources of Transcarpathia/Num. auth., (ed.), Bodnar V. L., Uzhgorod Carpathians, 284.

4. Braun-Blanquet J., 1964 - Pflanzensoziologie, Grundzüge der Vegetationskunde, (3. Auflage), Springer Verlag, Wien, 865. (in German)

5. Curtean-Bănăduc A., Schneider-Binder E. and Bănăduc D., 2014 - The importance of the riverine ligneous vegetation for the Danube Basin lotic ecosystems, in Cianfaglione K. (ed.), L’importanza degli Alberi e del Bosco, Cultura, scienza e coscienza del territorio, Temi Ed., Trento, Italia, ISBN: 978-88-973772-63-9, I-II, 187-210

6. De'camps H. and Tabacchi E., 1994 - Species richness in vegetation along river margins, in Giller P. S., Hildrew A. G. and Rafaelli D. G. (eds), Aquatic Ecology: Scale, Pattern and Process, Blackwell Scientific Publications, London, 1-10.

7. Dynesius M. and Nilsson C., 1994 - Fragmentation and flow regulation of river systems in the northern third of the world, Science, 266, 753-762.

8. Englund G., Jonsson B. G. and Malmqvist B., 1997 - Effects of flow regulation on bryophytes in North Swedish rivers, Biological Conservation, 79, 79-86.

9. Herenchuk K. I. (ed.), 1981 - Nature of Zakarpatska Oblast, Lviv: Publisher High School, 156. (in Ukrainian)

10. Maysuryan N. A. and Atabekova A. I., 1978 - The determinant of the seeds and fruits of weeds, Edition 2th, 288.

11. Naiman R. J. and De'camps H., 1997 - The ecology of interfaces: riparian zones, Annual Review of Ecology and Systematics, 28, 621-658.

12. Naiman R. J., De'camps H. and Pollock M., 1993 - The role of riparian corridors in maintaining regional biodiversity, Ecological Application, 3, 209-212.

13. Nilsson C. and Jansson R., 1995 - Floristic differences between riparian corridors of regulated and free-flowing boreal rivers, Regulation Rivers, 11, 55-66.

14. Nilsson C., Gardfjell M. and Grelsson G., 1991 - Importance of hydrochory in structuring plant communities along rivers, Canadian Journal of Botany, 69, 2631-2633.

15. Nilsson C., Nilsson E., Johansson M. E., Dynesius M., Grelsson G., Xiong S., Jansson R. and Danvind M., 1993 - Processes structuring riparian vegetation, Current Topics in Botanical Research, 1, 419-431.

16. Petts G., 1984 - Impounded Rivers: Perspectives for Ecological Management, Wiley, Chichester, 326.

17. Pop S. S., 2003 - Natural resources of the Transcarpathia, Uzhgorod: L. L. C. "Spektral”, 296. (in Ukrainian)

18. Prots B. 2010 - Europas unbekannte Urwälder in Transkarpatien, Ost-West, Europäische Perspektiven, 11, 3, 212-218. (in German)

19. Schneider R. L. and Sharitz R. R., 1986 - Seed bank dynamics in a southeastern riverine swamp, American Journal of Botany, 73, 7, 1022-1030.

20. Skoglund S. J., 1990 - Seed dispersing agents in two regularly flooded river sites, Canadian Journal of Botany 68, 754-60.

21. Ter Heerdt G. N. J., Verweij G. L., Bekker R. M. and Bakker J. P. 1996 - An improved method for seed-bank analysis: seedling emergence after removing the soil by sieving, Functional Ecology 10, 144-151.

22. Toner M. and Keddy P., 1997 - River hydrology and riparian wetlands: a predictive model for ecological assembly, Ecological Application, 71, 236-246. 
23. Willson M. F., 1992 - The ecology of seed dispersal, in Fenner (ed.) Seeds, The ecology of regeneration in plant communities, CAB International, Wallingford, 61-85.

24. Willson M. F., Rice B. L. and Westoby M., 1990 - Seed dispersal spectra: a comparison of temperate communities, Journal of Vegetation Science, 1, 547-560. 